\title{
All's Fair in Sport and Competition? The Application of EC Competition Rules to Sport
}

\author{
An Vermeersch
}

\begin{abstract}
The commercialisation and internationalisation of sporting activities alongside ongoing European integration has put the relationship between the European Union and the sports world under strain. The Bosman case marked the start of an intense debate on an appropriate regulatory framework for this evolving relationship. Whereas the Community judges in previous sport related cases had consistently opted for settling the dispute on the basis of free movement provisions, the Piau and the Meca-Medina \& Majcen cases entail the first rulings on the application of EC competition law to sport. This paper tackles the difficulty of separating the economic aspects from the sporting aspects of a sport and the consequences of anti-trust law for sporting associations. Whether the Court of Justice provided satisfactory guidelines to deal with upcoming legal actions and more generally, whether these guidelines on the application of competition law might influence the governance of sport in Europe, is also considered.
\end{abstract}

AS A GROWING ECONOMIC SECTOR, SPORT CANNOT ESCAPE THE APPLICATION OF European Community (EC) law. As early as 1974, the European Court of Justice (ECJ) issued the fundamental statement that 'the practice of sport is subject to Community law only in so far as it constitutes an economic activity within the meaning of Article 2 of the Treaty'.' Concurrently, it held that the rule of non-discrimination 'does not affect the composition of sport teams, in particular national teams, the formation of which is a question of purely sporting interest and as such has nothing to do with economic activity'2, suggesting that sport has some peculiarities and that purely sporting rules could be subject to a 'sporting exception'. Likewise, the Court emphasized that 'this restriction on the scope of the provisions in question must however remain limited to its proper objective'. ${ }^{3}$ While these principles were confirmed in later 'free movement cases', the precise scope and the concrete effect of the 'sporting exception' together with the question of whether these principles also applied in connection with competition law, remained unsolved.

The concept of the sporting exception is fundamental to understand the debates about the application of European Community (EU) law to the area of sport. However, the sporting exception has proven so far an elusive concept that is extremely difficult to define; particularly as those (sports governing bodies and other sporting organisations) that should be, in principle, most interested in identifying what the sporting exception is have not produced to date any intellectually compelling argument and/or definition of such a

\footnotetext{
${ }^{1}$ Case 36/74 Walrave and Koch v Union Cycliste Internationale [1974] ECR 1405, para 4.

2 ibid., para 8.

3 ibid., para 9.
}

The author would like to thank Kirstyn Inglis and the participants of the EUSA Tenth Biennial International Conference, in particular Dave Allen, Richard Parrish and Borja Garcia, for their comments on an earlier version of this article. The usual disclaimer applies. 
concept. ${ }^{4}$ In legal terms, the idea of a sporting exception stems from the first sport-related cases ruled by the ECJ, such as Walrave (1974) and Donà (1976). In those rulings, the Court considered sport subject to EC law, but, as explained above, it did also open a door to doubts. Therefore, in which cases is European law applicable to sport? If there is a sporting exception, does this mean that certain activities of sporting organisations are not subject to EC law? In brief, the idea of the sporting exception revolves around whether European law could/should/must be applied to the area of sport or not. ${ }^{5}$ The argument in favour of the sporting exception considers that sport, despite the economic dimension of the professional levels, is still different from other industries and, therefore, it merits (at least) a tailored application of European law, if not a total exemption. Those advocating for a special treatment of sport vis-à-vis EU law consider that the full application of the treaty provisions could endanger the socio cultural dimensions of sport. ${ }^{6}$ On the other hand, those negating the existence of the sporting exception are of the opinion that professional sport shall be subject to the full rigour of EU law. However, even if one agrees that sport deserves some kind of special treatment by EU law, it would be necessary to explain why and under what circumstances. So far, arguments in that regard are few and far between.

Those who are not familiar with the relationship between sport and the European Union will soon find that the sporting exception or similar ideas are constantly present in the discourses of EU institutions and sporting organisations. The sporting exception is a legal concept whose origins can be found in the case law of the ECJ. However, this concept has become politicised over time as European institutions had intervened in the debate on the application of EU law to sport. The political debate is normally focused around the so called specificity of sport. The specificity of sport refers to those characteristics that would make sport different from other industries ${ }^{7}$ and, therefore, meriting an exception from EU law. In a way, the specificity of sport is the political version of the sporting exception. If one recognises the specificity of sport, then one should also consider the application of the sporting exception and vice versa.

Elsewhere in this special issue Alfonso Rincón discusses the existence of the sporting exception from a legal point of view. In the article, Rincón analyses the case law of the European Court of Justice to try to find out whether the Court can be said to recognise the exception or not. This article deals with the specificity of sport in the application of Competition law to this sector. It analysis the application of competition rules to the sport sector so far.

For a long time, the ECJ judges refrained from ruling on the application of EC competition law to sport. In Bosman (1995) the Court of Justice did not consider it necessary to pronounce on the interpretation of the competition law provisions after it had found that the nationality clauses and transfer rules under consideration were contrary to the free movement rules. ${ }^{8}$ Both in Deliège (2000) and Lehtonen (2000) the Court also declined to rule on the matter because it had not been provided with sufficient information on the factual

\footnotetext{
${ }^{4}$ B. García (2007), 'From regulation to governance and representation: agenda-setting and the EU's involvement in sport', 1 Entertainment and Sports Law Journal 5, 8

${ }^{5}$ Sporting governing bodies advocated for quite some time that sport should be totally exempted of the application of EU law via the creation of a protocol on sport in the European treaties. See for example UEFA (2001), A Vision for European Sport: The Case for a Sport Protocol (UEFA)

${ }^{6}$ See for example R. Parrish (2003), Sports Law and Policy in the European Union (Manchester University Press) p. 68-71.

${ }_{7}$ These include the need for a balanced competition (Opel would be happy to see Renault disapear in the market, but Manchester United needs Liverpool to keep creating an exciting competition), the role of sport in the education of young athletes, the solidarity conection between professional and grassroots sport. In theory, sporting suceess should be decided on sporting merits on the court/pitch/track, not on financial strength.

${ }^{8}$ Case C-415/93 Union Royale Belge des Sociétés de Football Association v Bosman [1995] ECR I-4921, para 138.
} 
and legal background of the dispute..$^{9}$ The Court's reluctance to tackle this issue was perhaps understandable, but at the same time, regrettable. ${ }^{10}$ However, the silence of the ECJ suited the sporting world, which was not keen on getting a 'Bosman II' judgment from Luxembourg. This was plainly illustrated by the Balog case (1998)..1 This Hungarian professional football player had been playing between 1993 and 1997 for a Belgian first division team. After the expiry of his contract, he refused the new contract that his club offered him because the club had stated in the local press that Balog did not fit in the future plans of the club. Balog was put on the transfer list. Initially, no club was prepared to pay the transfer sum and when a Norwegian club wanted to engage Balog, the transfer could not be completed because the Belgian federation did not deliver the international transfer certificate requested. After having played for half a year on a loan basis in the Israeli first division, Balog challenged the transfer rules before a Belgian Court (in 1998). Because of his Hungarian nationality (non-EU at that time) he could not rely on the Bosman ruling. ${ }^{12}$ Consequently, he challenged the transfer rules (the abolition of transfer payments for out-ofcontract third country national players within the EU/European Economic Area (EEA) which was to enter into force only as of 1 April 1999) on the basis of EC competition law. ${ }^{13}$

As the Belgian Court referred the case to the ECJ, the Balog case was deemed to become the Court's first ruling on the application of competition law to sport. However, the sporting world managed to escape the verdict because, on the day Advocate General Stickx-Hackl was expected to deliver her opinion on the case, the football world and the player came to a settlement and agreed to drop the case. Consequently, for a long time, the only guidelines as regards the application of EC competition rules to sport resulted from the European Commission's handling of sport related competition cases and the opinion of some Advocates General, including Stix-Hackle's as she published her point of view in the aftermath of the Balog case. ${ }^{14}$

Already in 1999 the Commission tried to set some guidelines on the application of competition law to sport. The executive considered that from the perspective of EC competition law, practices/rules of sporting federations could be grouped into three categories: (1) practices which, in principle, do not come under competition rules, because they are inherent to sport and/or necessary for its organisation; (2) practices that are, in principle, prohibited by competition rules; (3) practices which are restrictive of competition but likely to be exempted from the competition rules. ${ }^{15}$ This framework was a useful starting point but in practice the borderlines between the different categories proved to be far from straightforward. ${ }^{16}$ Confirmation and fine tuning by the Community Courts (Court of First Instance and ECJ) was needed. The recent cases of Piau (CFI ruling in 2005 and ECJ's in 2006) and Meca-Medina (2004 and 2006) presented an excellent opportunity to the European Courts to clarify the criteria guiding the application of EU competition law to sport.

Moreover, the rulings in Piau and Meca-Medina have also been awaited because they provided the Court with a possibility to clarify what the special characteristics of sport are. A

\footnotetext{
9 Joined case C-51/96 and C-191/97 Deliège v Ligue francophone de judo et disciplines associées e.o. [2000] ECR I-2549, paras 36-38; Case C-176/96 Lehtonen en Castors Canada Dry Namur-Braine v Fédération royale belge des sociétés de basketball [2000] ECR I-2681, paras 28-30.

${ }^{10} \mathrm{~A}$. Bell and P. Turner-Kerr (2002), 'The place of Sport Within the Rules of Community Law: Clarification from the ECJ? The Deliège and Lehtonen Cases', E.C.L.R. 256, 256.

${ }_{11}$ Case C-264/98 Balog v Royal Charleroi Sporting Club ASBL (removed from the register on 2/4/01).

${ }^{12}$ S. Van den Bogaert (2005), Practical Regulation of the Mobility of Sportsmen in the EU Post Bosman (Kluwer Law International) p 105.

${ }^{13}$ Case C-264/98 Balog v Royal Charleroi Sporting Club ASBL (removed from the register on 2/4/01), Rapport d'audience, para 8.

${ }^{14}$ A. Egger and C. Stix-Hackl (2002), 'Sports and Competition Law: A Never-ending Story?', E.C.L.R. 81.

15 'Commission debates application of its competition rules to sport', IP/99/133; Report from the European Commission to the European Council with a view to safeguarding current sports structures and maintaining the social function of sport within the Community framework ('The Helsinki Report on Sport'), COM (1999) 644.

${ }^{16}$ S. Weatherill (2003), “Fair Play Please!': Recent developments in the application of EC law to sport', CML Rev. $51,82$.
} 
distinction can be drawn in the approaches of EU institutions to the special characteristics. ${ }^{17}$ On the one hand, there is a political/theoretical/sociological approach that relates to the multifunctional role of sport (health enhancing, educational). This approach has been followed in a number of policy documents, such as the Nice Declaration (2000). ${ }^{18}$ On the other hand, there is a more legal/pragmatic side, followed by the Community Courts and by the European Commission when dealing with the application of EC law to sport, according to which some specific characteristics of sport are taken into account. There are many examples in which the ECJ rulings and Commission decisions have taken into account the characteristics of sport to apply Treaty provisions to the sector. Examples relate to the equality between participants and the uncertainty of the results. ${ }^{19}$ This is closely linked with the idea that there is a difference '[...] between the way competition works in sport and in economic sectors'..$^{20}$ In addition, the primary role of the sports federations in the regulation of sporting competitions has been also explicitly acknowledged by the Courts (transfer windows were considered legal in Lehtonen; selection criteria for international competitions in Deliège; and doping rules in Meca-Medina, all of them laid down by governing bodies in fulfilment of their roles as guardians of their respective sports, a role recognised in the judgements).

In addition, the Piau and Meca-Medina cases provided the possibility to take away some doubts regarding the correct application of the 'sporting exception'. The reason for this uncertainty was two-fold. First, the Court's reasoning in Walrave that competitions between national (football) teams have 'nothing to do with economic activity' seemed hard or even impossible to justify. Arguably, this can only be understood as a confirmation of a general feeling that the competition between national teams is a matter of 'national pride and identity'. ${ }^{21}$ Second, it remained unclear what the concrete legal effect of the recognition of a 'purely sporting' rule was. Whereas the Court in Walrave made clear that the rules at issue fell outside the scope of EC law ${ }^{22}$, in Bosman the purely sporting context was only mentioned as a possible justification to a rule which was caught by EC law. ${ }^{23}$ The possible confusion arising from the divergence between Walrave and Bosman was strengthened by the Court's ruling in two later cases. ${ }^{24}$ The Walrave approach seemed to be endorsed in Deliège, where the selection criteria from the Belgian judo federation to participate in international tournaments were scrutinised. The Court held that although the selection rules at issue 'inevitably have the effect of limiting the number of participants in a tournament, such a limitation is inherent in the conduct of an international high-level sports event, which necessarily involves certain selection rules or criteria being adopted. Such rules may not therefore be regarded in themselves as constituting a restriction on the freedom to provide services prohibited by Article 59 of the Treaty'. ${ }^{25}$ Conversely, in Lehtonen, the Court found that the transfer deadlines set by the Belgian basketball federation constituted an obstacle to the free movement of professional basketball players that could be justified by the objective of ensuring the

\footnotetext{
${ }^{17}$ C. Miège (2006), 'Le sport dans I'Union européenne: entre spécificité et exception?', Etudes Européennes, available at: <http://www.etudes-europeennes.fr>.

${ }^{18}$ Declaration on the specific characteristics of sport and its social function in Europe, of which account should be taken in implementing common policies, annexed to the Conclusions of the Nice European Council (7,8 and 9 December 2000), Bulletin EU 12-2000.

${ }^{19}$ Case C-415/93 Union Royale Belge des Sociétés de Football Association v Bosman [1995] ECR I-4921, para 106; Case C-519/04 P Meca-Medina \& Majcen v Commission [2006] ECR I-6991, paras 43-45.

${ }^{20}$ Mario Monti, Competition and Sport the Rules of the Game, SPEECH/01/84.

${ }^{21}$ Weatherill, 'Discrimination on Grounds of Nationality in Sport', in A. Barav and D.A. Wyatt (eds), Yearbook of European Law 1989 (Clarendon Press, 1990) p 60.

${ }^{22}$ Case 36/74 Walrave and Koch v Union Cycliste Internationale [1974] ECR 1405, paras 8-9.

${ }^{23}$ Case C-415/93 Union Royale Belge des Sociétés de Football Association v Bosman [1995] ECR I-4921, para 76.

${ }^{24}$ P. Ibáñez Colomo (2006), 'The Application of EC Treaty Rules to Sport: the Approach of the European Court of First Instance in the Meca-Medina and Piau cases', 2 ESLJ 3, available at: <http://www2.warwick.ac.uk/fac/soc/law/elj/eslj/issues/volume3/number2/colomo/>.

25 Joined case C-51/96 and C-191/97 Deliège v Ligue francophone de judo et disciplines associées e.o. [2000] ECR I-2549, para 64.
} 
regularity of sporting competitions. ${ }^{26}$ Even if one could explain the (seemingly) mystified case-law by the fact that the Court showed more clemency towards international competitions between national teams and non-discriminatory rules, ${ }^{27}$ further guidance from the Court on the concrete application of the 'sporting exception' was still needed.

\section{Meca-Medina \& Majcen: Wouters confirmed, 'sporting exception' curtailed}

David Meca-Medina and Igor Majcen are two professional long distance swimmers who tested positive for nandralone. The international swimming federation suspended both athletes for a period of two years. Meca-Medina and Majcen filed a complaint with the European Commission, challenging the compatibility of the International Olympic Committee's (IOC) anti-doping regulation with the Community competition rules. In other words, the swimmers argued that the IOC was abusing its dominant position as a sport governing body by adopting unilaterally rules on doping. The Commission concluded that the anti-doping legislation did not fall foul of the prohibition under Articles 81 and $82 \mathrm{EC}$ and rejected the complaint. ${ }^{28}$ Meca-Medina and Majcen brought their action before the Court of First Instance (CFI), which stipulated that 'the principles extracted from the case-law, as regards the application to sporting regulations of the Community provisions in respect of the freedom of movement of persons and services, are equally valid as regards the Treaty provisions relating to competition'. ${ }^{29}$ The CFI stated that purely sporting legislation may have nothing to do with economic activity, and as such does not fall within the scope of Articles 39 and $49 \mathrm{EC}$. This means also that it has nothing to do with the economic relationships of competition and therefore that it also does not fall within the scope of Articles 81 and 82 EC. ${ }^{30}$ Contrary to the Commission, the Court of First Instance did not examine whether the sport at issue could be qualified as an economic activity within the meaning of Article $2 \mathrm{EC}$. Nor did it examine whether the IOC (or the international swimming federation) had to be considered as undertakings or associations of undertakings. The CFI directly assessed the 'purely sporting' nature of the anti-doping regulation. It acknowledged that high-level sport has become, to a great extent, an economic activity, but pointed out that the fight against doping does not pursue an economic objective. As the campaign against doping intends to safeguard the health of athletes and to preserve the spirit of fair play, 'it forms part of the cardinal rule of sport'. ${ }^{31}$ The CFI emphasised that 'sport is essentially a gratuitous and not an economic act, even when the athlete performs it in the course of professional sport'. 32 Therefore, it concluded that the prohibition of doping and the anti-doping legislation concern exclusively 'a non-economic aspect of that sporting action, which constitutes its very essence'. ${ }^{33}$ Consequently, the rules to combat doping 'are intimately linked to sport' [...] and do not come within the scope of Articles 49, 81 and $82 \mathrm{EC} .{ }^{34}$ The CFI rejected the two arguments brought forward by Meca-Medina and Majcen on the economic nature of the contested anti-doping regulation. In its opinion, the eventual economic repercussions for the athletes and the fact that the IOC might possibly have had in mind the economic potential of the Olympic Games when adopting the anti-doping legislation, 'is not sufficient to alter the purely sporting nature of that legislation'. ${ }^{35}$ On these grounds, the Court of First Instance dismissed the swimmer's action.

\footnotetext{
${ }^{26}$ Case C-176/96 Lehtonen en Castors Canada Dry Namur-Braine v Fédération royale belge des sociétés de basketball [2000] ECR I-2681, paras 47-60. In reality, the Court questioned the stricter deadlines for players from the European zone compared to players from others zones.

${ }^{27}$ P. Ibáñez Colomo, 'The Application of EC Treaty Rules to Sport', n 24 above.

${ }^{28} \mathrm{COMP} / 38.158$, Meca-Medina et Majcen $v \mathrm{CIO}$.

${ }^{29}$ Case T-313/02 Meca-Medina \& Majcen v Commission [2004] ECR II 3291, para 42.

30 ibid., para 44.

31 idem.

32 ibid., para 45.

33 idem.

${ }^{34}$ Remarkably, the CFI emphasised that if the anti-doping legislation would be discriminatory in nature, it would not escape the Treaty provisions (paras 47-49).

35 ibid., paras 51-57.
} 
Whereas the final outcome of this case could be defended in the sense that anti doping rules should be accepted because they try to protect the integrity of sport, the reasoning of the Court of First Instance to reach that conclusion seems less convincing. Admittely, the exclusively sporting nature of drug control rules was recognised in English case law. ${ }^{36}$ Conversely, the Swiss Federal Court has stated that the suspension from international competitions exceeds a simple rule/sanction assuring the smooth progress of sporting competitions. ${ }^{37}$ What is at stake, is the problematic attempt to make a clear distinction between purely sporting and economic rules. ${ }^{38}$ Whereas anti-doping rules are not primarily aimed at profit making, they clearly have economic repercussions. Therefore, they can be regarded as both 'sporting' and 'economic' in nature. ${ }^{39}$ Moreover, by qualifying anti-doping rules as rules of a purely sporting interest which therefore fall outside the scope of Community law, it appears that the Court of First Instance did indeed granted too much room for manoeuvre to the sporting federations. ${ }^{40}$

On appeal, the Court of Justice set aside the Court of First Instance's judgment. ${ }^{41}$ The Court of Justice largely relied on its longstanding case law on sport but added two new elements of great consequence. ${ }^{42}$ It started by recalling that sport is subject to Community law in so far as it constitutes an economic activity. Again referring to Walrave, the Court continued that the prohibitions enacted by the Treaty provisions do not affect rules concerning questions which are of purely sporting interest. ${ }^{43}$ With regard to the difficulty of severing the economic aspects from the sporting aspects of a sport, the Court confirmed, referring to Donà, Bosman and Deliège, that the provisions on free movement of persons and the freedom to provide services do not preclude rules or practices justified on non-economic grounds which relate to the particular nature and context of certain sporting events. However, such a restriction on the scope of the provisions in question must remain limited to its proper objective. ${ }^{44}$ So far this only confirms the established case law on sport. In paragraph 27 of the Meca-Medina judgement, the ECJ introduces a first new element. Contrary to the Court of First Instance, the Court does not try to make an artificial distinction between the economic and sporting aspects of the sporting activity at stake. The Court draws a distinction between the activities of sportsmen and the rules governing these activities. According to the Court, '[...] it is apparent that the mere fact that a rule is purely sporting in nature does not have the effect of removing from the scope of the Treaty the person engaging in the activity governed by that rule or the body which has laid it down'. ${ }^{45}$ In other words, a sporting case can involve both economic and non-economic aspects and the non-economic elements do not (always) suffice to remove the case from the scope of Community law. Moreover, 'If the sporting activity in question falls within the scope of the Treaty, the conditions for engaging in it are then subject to all the obligations which result from the various provisions of the Treaty. It follows that the rules which govern that activity must satisfy the requirements of those provisions, which, in particular, seek to ensure freedom of movement for workers, freedom of establishment, freedom to provide services, or competition'. ${ }^{46}$ Thereupon, the ECJ ruled that the Court of First Instance made an error of law by holding that rules could automatically be

\footnotetext{
${ }^{36}$ English High Court Edwards $v$ the British Athletic Federation and the International Amateur Athletic Federation [1998] 2 CMLR 363-371. See also I. Blackshaw. (2005), 'Doping Is a Sporting, Not an Economic Matter', 3-4 ISLJ 51.

37 Ligue Suisse de Hockey sur Glace contre Dubé [1994] BGE 120 II 369, available at: $<$ http://www.bger.ch/fr/index/juridiction/jurisdiction-inherit-template/jurisdiction-recht/jurisdiction-rechtleitentscheide1954.htm>; G. contre Fédération Equestre Internationale et tribunal arbitral du Sport [1993] BGE 119 II 271, available at : <http://www.bger.ch/fr/index/juridiction/jurisdiction-inherittemplate/jurisdiction-recht/jurisdiction-recht-leitentscheide1954.htm>.

${ }^{38}$ S. Weatherill (2005), 'Anti-Doping Rules and EC Law', E.C.L.R. 416.

39 ibid., 420.

40 S. Van den Bogaert and A. Vermeersch (2006), 'Sport and the European Treaty: A Tale of Uneasy Bedfellows?', E.L.Rev. 821, 834.

${ }^{41}$ Case C-519/04 P Meca-Medina \& Majcen v Commission [2006] ECR I-6991.

42 ibid., para 22.

43 lbid., para 25.

44 Ibid., para 26.

45 ibid., para 27.

46 ibid., para 28.
} 
excluded from the scope of EC competition law (Articles 81 and 82 EC Treaty) on the sole ground that they were regarded as purely sporting with regard to the application of the free movement provisions, without any need to determine first whether the rules fulfilled the specific requirements of Articles 81 and $82 \mathrm{EC} .{ }^{47}$ When an activity must be assessed under EC competition law, it will be necessary to determine whether the rules which govern that activity emanate from an undertaking, whether the latter restricts competition or abuses its dominant position, and whether that restriction or that abuse affects trade between Member States. ${ }^{48}$ It is unclear whether the Court's statement should be interpreted as a general rejection of the trend towards convergence - to a certain extent - that some authors see between the provisions on free movement and the competitions rules. ${ }^{49}$ The Court does not elaborate on this, but it seems apparent that the Court of Justice firmly criticised the halfhearted analysis of the Court of First Instance, rather than turning down the convergence theory..$^{50}$ The latter would need further confirmation by the Court of Justice. As Weatherill convincingly advocates, with regard to the application of EC principles to sport, it seems appropriate to plea for a 'convergence in outcome'. ${ }^{51}$ What is or is not acceptable under free movement provisions should also be acceptable or not under EC competition law, and vice versa. This is not to say that the legal reasoning under both strands of Community law should be identical.

When judging on the concrete questions at issue in Meca Medina, the Court of Justice added a second new element to its previous sport related case-law. The Court relied on the Wouters judgment to examine the contested anti-doping rules. ${ }^{52}$ According to the Court, 'the compatibility of rules with the Community rules on competition cannot be assessed in the abstract'..$^{53}$ Therefore, the Court investigated whether the anti-doping rules are intimately linked to the proper conduct of sporting competition, whether they are necessary to combat doping effectively and whether the limitation of athletes' freedom of action does not go beyond what is necessary to attain that objective. ${ }^{54}$ The Court stated that the Commission rightly took the view that the contested rules served the objective of guaranteeing fair competitive sport. By this means, the Court recognised the significance of safeguarding equal chances for athletes, athletes' health, the integrity and objectivity of competitive sport and the ethical values in sport. ${ }^{55}$ Moreover, 'given that penalties are necessary to ensure enforcement of the doping ban, their effect on athletes' freedom of action must be considered to be, in principle, inherent itself in the anti-doping rules'. ${ }^{56}$ The Court did not explicitly state that the anti-doping rules at issue were to be regarded as a decision of an association of undertakings that limits the freedom of action, but asserted directly that they were justified by a legitimate objective. However, this does not automatically put the contested anti-doping rules outside the prohibitions in Article 81 EC. The Court acknowledges that the penal nature of the anti-doping rules and the magnitude of the penalties applicable 'are capable of producing adverse effects on competition' ${ }^{57}$ If penalties were ultimately to prove unjustified they could result in an athlete's unwarranted exclusion from sporting events and accordingly in lopsided conditions. Therefore, the Court of Justice

\footnotetext{
47 ibid., paras 29-34.

48 ibid., para 30.

${ }^{49}$ K.J.M. Mortelmans (2001), 'Towards convergence in the application of the rules on free movement and on competition', C.M.L.Rev. 613; R. Nazzini , 'Article 81 EC between time present and time past : a normative critique of "restriction of competition" in EU law, (2006) C.M.L.Rev. 497; R. O'Loughlin (2003), 'EC Competition Rules and Free Movement Rules: An Examination of the Parallels and their Furtherance by the ECJ Wouters Decision', E.C.L.R. 62.

${ }^{50} \mathrm{~S}$. Weatherill, 'Anti-doping revisited - the demise of the rule of 'purely sporting interest?', (2006) E.C.L.Rev. 645,649 .

51 idem.

52 Case C-309/99 Wouters e.o. v Algemene Raad van de Nederlandse Orde van Advocaten [2002] ECR I-1577.

${ }^{53}$ Case C-250/92 Goettrup-Klim e.o. Grovvareforeninger v Dansk Landbrugs Grovvareselskab AMBA [1994] ECR I-5641, para 31. Hereinafter, DLG.

${ }^{54}$ Case C-309/99 Wouters e.o. v Algemene Raad van de Nederlandse Orde van Advocaten [2002] ECR I-1577, para 97; Case C-519/04 P Meca-Medina \& Majcen v Commission [2006] ECR I-6991, para 42.

${ }_{55}$ Case C-519/04 P Meca-Medina \& Majcen v Commission [2006] ECR I-6991, para 43.

56 ibid., para 44.

57 ibid., para 47.
} 
ruled that 'in order not to be covered by the prohibition laid down in Article 81(1) EC, the restrictions thus imposed by those rules must be limited to what is necessary to ensure the proper conduct of competitive sport'..$^{58}$ According to the Court, the contested doping rules could be excessive in two ways: first with regard to the conditions underlying the dividing line between circumstances that amount to doping, in respect of which penalties may be imposed and those which do not, and second with regard to the severity of those penalties. The Court refrained from making a detailed analysis. Concerning the former, the Court referred to the scientific knowledge as it stood at the time the anti-doping rules were adopted and applied to Meca-Medina and Majcen. On this basis and because the appellants did not specify at what level the threshold in question should have been set, the Court found that the restrictions that follow from this threshold for professional sportsmen were not excessive. ${ }^{59}$ On the severity of the penalties, the Court's assessment remained shallow: as the appellants did not bring this element up, the Court stated that 'it has not been established that the anti-doping rules at issue are disproportionate' ${ }^{60}$

The Court's reticence towards a more elaborated assessment can be deplored, ${ }^{61}$ but is comprehensible. It seems logical that it is not the task of judges to enter into the details of the specific and technical anti-doping regulation. Along these lines, the confirmation of Wouters in Meca-Medina can be seen as an 'important and welcome development in the light of the tendency towards greater self-regulation in the EU' ${ }^{62}$ However, the Court's ruling illustrates that a marginal assessment can be carried out by the Community judges. Moreover, by simply raising the issue of the severity of the penalties, the Court leaves future doping offenders the possibility of challenging the doping penalties on the basis of EC law. The sporting federations are warned: the proportionality principle must be taken into account when setting doping penalties and it is not excluded that the Court of Justice will assess the issue in greater detail when it would be raised in future litigation.

\section{Wouters approach not new in sporting context}

On the basis of the foregoing analysis, the Court of Justice dismissed the action brought by the appellants and confirmed the Commission's rejection of their complaint. Even if the outcome of both rulings was identical, the analysis of the ECJ is to be preferred to the approach of the CFI. Arguably, by applying the Wouters approach, the ECJ found an appropriate way of tackling the difficulty of severing the economic from the sporting aspects of a sporting case. This approach has the double advantage of not a priori excluding sport related cases from the application of EC law and, at the same time, taking into account the peculiarities of sport. Even if the precise scope and implications of the Wouters judgment remain unclear, ${ }^{63}$ and even if the judgment was heavily criticised, it seems to provide a plausible basis for reconciling EC competition law with sport.

This can inter alia be deduced from the fact that in the past a Wouters like approach was followed on several occasions. In sporting cases that predate the Wouters judgment (19 February 2002), reference was made to the DLG (1994) case which is considered to be the predecessor of the Wouters judgment. ${ }^{64}$ The DLG case concerned the statutes of a cooperative purchasing association in the agricultural sector. The Court of Justice stated that a provision in these statutes forbidding the association's members to participate in other forms of organised cooperation that are in direct competition with it, was not caught by the

\footnotetext{
58 idem. The Court referred to paragraph 35 of the case DLG.

${ }^{59}$ Case C-519/04 P Meca-Medina \& Majcen v Commission [2006] ECR I-6991, paras 49-54.

60 ibid., paras 49-55.

61 J.M. Sluijs and M.C.A. Van Woerkom. (2006), 'Meca-Medina en Majcen (hogere voorziening): Convergentie gepreciseerd, Wouters bevestigd', NTER 248, 253.

62 E. Szyszczak (2007), 'Competition and sport', E.L.Rev. 95, 106.

${ }^{63}$ For an overview see e.g. J.W. Van de Gronden and K.J.M. Mortelmans (2002), 'Wouters: is het beroep van advocaat een aparte tak van sport?', Ars Aequi 441.

${ }^{64}$ Case C-250/92 Goettrup-Klim e.o. Grovvareforeninger v Dansk Landbrugs Grovvareselskab AMBA [1994] ECR I-5641, para 31; E. Szyszczak, 'Competition and sport', n 62 above.
} 
prohibition in Article 81(1) EC, 'so long as the abovementioned provision is restricted to what is necessary to ensure that the co-operative functions properly and maintains its contractual power in relation to producers'.$^{65}$ The $D L G$ case, which forms an example of the ancillary restraints doctrine, ${ }^{66}$ was referred to by several advocates general when dealing with sporting cases. In Bosman, Advocate General Lenz mentioned DLG as it was brought up by UEFA. ${ }^{67}$ The Advocate General emphasised that the case showed that only those restrictions of competition which are indispensable for attaining the legitimate objectives pursued by them do not fall within the prohibition of Article 81 . Finding the nationality clauses and transfer rules at issue not necessary or indispensable for the proper functioning of the football sector, he held that the possible beneficial effects of those provisions could therefore be examined only in the context of Article 81(3). This view was confirmed by Advocate General Stix-Hackl in her informal opinion in the Balog case. ${ }^{68}$ The Advocates General in Deliège and Lehtonen both relied on DLG. ${ }^{69}$ Admittedly, their analysis on the applicability of the competition rules was only considered in the alternative as the national judges had not provided all details to make an elaborate analysis. In Lehtonen Advocate General Alber held that the transfer periods at stake probably entailed a restriction of competition within the meaning of Article 81(1) EC because they prevent clubs 'from increasing the attractiveness of their product by taking on new players during a certain period'. ${ }^{70}$ Simultaneously, these transfer windows guarantee comparability of results of matches within a season. As that objective is decisive for the competition between clubs which consists in increasing the attractiveness of their matches, Alber concluded that the transfer periods were therefore compatible with Article $81 \mathrm{EC}$, however, only to the extent that they may be reconciled with the freedom of movement for workers. ${ }^{71}$ In Deliège, Advocate General Cosmans held that even if the contested selection criteria 'were to be regarded as reducing competition, in the sense that they prevent certain judokas from taking part in certain international tournaments, the contested rules do not fall within the scope of [Article $81 \mathrm{EC}$ ] because they are indispensable for attaining the legitimate objectives deriving from the particular nature of judo'.72 In the pre-Wouters period, the European Commission also relied on the $D L G$ approach in sport related cases, albeit without explicitly mentioning the case. This was illustrated by its statement in the Helsinki Report on Sport that some sporting practices do not come under competition rules because they are inherent to sport and/or necessary for its organisation..$^{73} \mathrm{~A}$ concrete application can be found in the Mouscron case (1999). ${ }^{74}$ The case concerned a complaint from the Communauté Urbaine de Lille who challenged UEFA's decision not to allow the UEFA Cup game between the Belgian club Mouscron (a town near the French border) and Metz to be played in Lille (France). In practice, this meant that Lille was unable to hire out its stadium to Mouscron. The decision was based on an UEFA rule which stipulated that, apart from very exceptional circumstances, every club must play its home match at its own ground. The Commission rejected the complaint because it considered that UEFA's 'at home and away from home' rule is needed 'to ensure

\footnotetext{
${ }^{65}$ Case C-250/92 Goettrup-Klim e.o. Grovvareforeninger v Dansk Landbrugs Grovvareselskab AMBA [1994] ECR I-5641, para 45.

${ }^{66}$ A. Jones and B. Sufrin (2004), EC Competition Law (Oxford University Press) p 216-220.

${ }^{67}$ Conclusion Advocate General Lenz in Case C-415/93 Union Royale Belge des Sociétés de Football Association v Bosman [1995] ECR I-4921, paras 268-270.

${ }^{68}$ A. Egger and C. Stix-Hackl, 'Sports and Competition Law', n 14 above.

${ }^{69}$ Conclusion Advocate General Cosmans in Joined case C-51/96 and C-191/97 Deliège v Ligue francophone de judo et disciplines associées e.o. [2000] ECR I-2549, paras 89-114; Conclusion Advocate General Alber in Case C-176/96 Lehtonen en Castors Canada Dry Namur-Braine v Fédération royale belge des sociétés de basketball [2000] ECR 2000, I-2681, paras 94-110.

${ }^{70}$ Conclusion Advocate General Alber in Case C-176/96 Lehtonen en Castors Canada Dry Namur-Braine v Fédération royale belge des sociétés de basketball [2000] ECR 2000, I-2681, para 105.

71 ibid., para 108.

${ }^{72}$ Conclusion Advocate General Cosmans in Joined case C-51/96 and C-191/97 Deliège v Ligue francophone de judo et disciplines associées e.o. [2000] ECR I-2549, para 112.

${ }^{73}$ European Commission, Helsinki Report on Sport, n. 16 above

74 'Limits to application of Treaty competition rules to sport: Commission gives clear signal', European Commission Press release IP/99/965, 9 December 1999. However, the Commission also referred to the lack of Community interest.
} 
equality between clubs', thereby recognising the legitimate right of self regulation of a sporting organisation. ${ }^{75}$

After the Wouters judgment, the Commission settled two sporting cases with explicit reference to Wouters. In the case of ENIC (1999), UEFA's multi-ownership rule according to which a company or individual cannot directly or indirectly control more than one of the clubs participating in a UEFA club competition, was under scrutiny.$^{76}$ ENIC, a company that owned stakes in six European clubs in five different countries lodged a complaint with the European Commission stating that the rule distorted competition by preventing and restricting investment in European clubs. According to the Commission, the question to answer was whether 'the consequential effects of the rule are inherent in the pursuit of the very existence of credible pan European football competitions'. ${ }^{77}$ In a preliminary conclusion the Commission stated that the rule could be qualified as a decision of an association of undertakings or an agreement between associations of undertakings inside UEFA but that the restrictions imposed by the rule may escape the prohibition laid down in Article 81(1) EC. Before coming to a final verdict, the Commission invited third parties to send observations as to whether the restrictions were limited to what is necessary 'to preserve the integrity of the UEFA club competitions and to ensure the uncertainty as to results'. ${ }^{78}$ The Commission referred to the recognition of legitimate objectives in the view of the considerable social importance of football in the Community by the Court of Justice in Bosman and the opinion of Advocate General Alber in Lehtonen. In addition, the Commission mentioned the decision of the Court of Arbitration for Sport in the case of AEK Athens and Slavia Prague v UEFA (1998) where the contested rule was approved because it preserves or even enhances economic and sporting competition. ${ }^{79}$ In its final decision, the Commission held that a rule may fall outside the scope of competition rules despite possible negative business effects, provided that it does not go beyond what is necessary to ensure its legitimate aim - in casu the protection of the uncertainty of the results - and consequently rejected the complaint. ${ }^{80}$ In Meca-Medina the Commission quoted Wouters for a second time. ${ }^{81}$ The Commission came to the conclusion that the anti-doping rules at issue are intimately linked to the proper conduct of sporting competition, that they are necessary to combat doping effectively and that the limitation of an athlete's freedom of action does not go beyond what is necessary to attain that objective. Accordingly, the Commission concluded that these rules did not contravene the prohibition under Article 81 EC.$^{82}$ When the case came on appeal before the Court of First Instance, the Commission played down the influence of Wouters in reaching its decision. The Commission stated at the hearing, in reply to a question from the Court, that the disputed decision was based on Walrave, Donà and Deliège and therefore, on the purely sporting nature of the anti-doping rules at issue. The Wouters based analysis under competition law served only 'in the alternative' or 'for the sake of completeness'. ${ }^{83}$ The explicit confirmation of the Wouters approach by the Court of Justice in Meca-Medina validates the direction that was followed by the Commission and several advocates general in previous sporting cases. Moreover, it confirms several authors' plea to use Wouters in a sporting context. ${ }^{84}$

\footnotetext{
75 idem.

76 'Commission closes investigation into UEFA rule on multiple ownership of football clubs', IP/02/942; Letter from Commissioner Mario Monti to ENIC, Case COMP/37.806; Communication made pursuant to Article 19(3) of Council Regulation No 17 concerning request for negative clearance or for exemption pursuant to Article 81 (3) of the EC Treaty (Case No 37.632 - UEFA rule on 'integrity of UEFA club competitions: independence of clubs') [1999] OJ C 363/2.

77 Case COMP/37.806.

${ }^{78}$ Case COMP/37.632.

${ }^{79}$ CAS 98/200 AEK Athens and Slavia Prague v UEFA; Case COMP/37.632.

80 'Commission closes investigation into UEFA rule on multiple ownership of football clubs', IP/02/942.

${ }^{81}$ Case COMP/38.158, para 43.

82 ibid., para 55.

${ }^{83}$ Case T-313/02 Meca-Medina \& Majcen v Commission [2004] ECR II 3291, para 62.

${ }^{84}$ S. Weatherill, 'Anti-Doping Rules and EC Law', n 38 above; R. WHISH, Competition Law (Butterworths, 2003) p 122-124.
} 


\section{Sport and EC competition law after Meca-Medina \& Majcen}

As the Court of Justice in Meca-Medina unequivocally indicated that sporting rules do not $a$ priori escape the application of EC competition law the first step in analysing whether a given sporting rule conflicts with EC competition law, will be to examine whether the sporting rule at stake meets the conditions of Articles 81(1) and $82 \mathrm{EC}$. In this respect, three major aspects must be taken into account. As many elements of this analysis were recently under consideration in the Piau case, the facts of this case are illuminated first.

The case of Piau, the second sporting case where the Community judges scrutinised a provision in the statues of a sporting federation under EC competition law, concerned the validity of the FIFA Players' Agents Regulations. ${ }^{85}$ Piau, who wanted to become a players' agent himself, had lodged a complaint with the European Commission. He considered that the regulations were contrary to EC competition law because of the restrictions on the access to the profession. Following the opening of a competition procedure by the Commission, FIFA agreed to alter its regulations. The new regulations maintained the obligation to hold a licence issued by the competent national (football) association for an unlimited period, but entailed some changes in order to make the licensing procedure more objective and transparent. The oral interview was replaced by an examination in the form of a multiple choice test and the obligatory bank deposit was replaced by the choice between taking a liability insurance and a bank deposit. Moreover, the regulations stipulated that the relations between the agent and the player must be the subject of a written (renewable) contract for a maximum period of two years, specifying the agent's remuneration (to be calculated on the basis of the player's basic gross salary) and established a system of sanctions for clubs, players and agents. On this basis, the Commission decided to take no further action and rejected Piau's complaint for a lack of Community interest. ${ }^{86}$ Piau challenged this decision before the Court of First Instance.

\section{Undertakings and associations of undertakings}

As Article 81(1) EC applies to 'undertakings' and 'associations of undertakings' and Article 82 EC applies to 'undertakings', these concepts entail a first key element to consider. The term 'undertaking' was given a broad interpretation in the ECJ's case-law. It 'encompasses every entity engaged in an economic activity, regardless of the legal status of the entity and the way in which it is financed'. ${ }^{87}$ An economic activity is any activity that involves 'offering goods or services on the market'.88 It is irrelevant that the body is not profit-making or that it is not set up for an economic purpose. ${ }^{89}$ As a consequence of this functional approach, sporting bodies can also be considered as undertakings. ${ }^{90}$ Already in 1992, in the case on the distribution of package tours during the 1990 World Cup, the Commission held that FIFA, the Italian football federation and the local organising committee carried on activities of an economic nature and consequently, constituted undertakings within the meaning of Article 81 EC.91 This was confirmed in several sporting cases. Regarding (football) clubs, the Commission confirmed this - inter alia - in ENIC, because, through their team, the clubs

\footnotetext{
${ }^{85}$ Case COMP/37.124; Case T-193/02 Laurent Piau v Commission [2005] ECR II-209; Case C-171/05 P Laurent Piau v Commission [2006] I-37.

${ }^{86}$ Case COMP/37.124.

${ }^{87}$ Case C-41/90 Höfner and Elser v Macrotron GmbH [1991] ECR I-1979, para 21.

${ }^{88}$ Case 118/85 Commission v Italy [1987] ECR 2599, para 7.

${ }^{89}$ Case C-67/96 Albany International BV v Stichting Bedrijfspensioenfonds Textielindustrie [1999] ECR I-5751, paras 79 and 85; Case C-475/99 Ambulanz Glöckner v Landkreis Südwestpfalz [2001] ECR I-8089, paras 19-21. ${ }_{90}$ A. Jones and B. Sufrin, EC Competition Law , n 66 above, p 108-110.

${ }^{91}$ Case IV/33.384 and IV/33.378 Distribution of package tours during the 1990 World Cup [1992] OJ L 326/31. The Commission came to the conclusion that the parties had infringed Article 81(1) EC for restrictive sales terms for tour packages and thus making it impossible for other tour operators and travel agencies to find other sources of supply. However, since it was the first time that the Commission had taken action on the distribution of tickets for a sporting event, and because the case involved complicating factors in view of safety aspects and because the infringement came to an end with the completion of the 1990 World Cup, the Commission decided not to impose a fine.
} 
supply 'sporting entertainment by playing matches against other clubs, usually in the context of a championship. These events are made available against payment (admission fees and/or radio and television broadcasting rights, sponsorship, advertising, merchandising, etc.) on several markets'.92 The Court of First Instance confirmed this viewpoint in the Piau case..$^{93}$ National sporting associations can be both undertakings and associations of undertakings. When these associations carry out economic activities themselves, for instance by selling broadcasting rights or by the commercial exploitation of a sport event, they are to be considered as undertakings. ${ }^{94}$ In Piau, the Court of First Instance considered that the national football associations - 'groupings of football clubs for which the practice of football is an economic activity' - constitute associations of undertakings. ${ }^{95}$ The fact that these federations group both amateur and professional clubs does not alter this qualification. ${ }^{96}$ In addition, international sporting federations can be both undertakings and associations of undertakings. ${ }^{97}$ At the same time, an international governing body can be an association of associations of undertakings. ${ }^{98}$

The question of whether an individual athlete can be considered as an undertaking had not thus far been addressed by the Commission or the Community judges. Whereas Advocate General Lenz found in his conclusion on the Bosman case that football players had to be considered as employees and did not constitute undertakings, this does not exclude that individual sportsmen might be considered to be undertakings for the purpose of articles 81 and $82 \mathrm{EC} .{ }^{99}$ Reference can be made to the Deliège case where the Court of Justice held that a high level athlete (judoka) participating in an international competition exercised an economic activity, although she was not remunerated by the organiser. ${ }^{100}$ Therefore, (independent) individual athletes may constitute undertakings within the meaning of EC competition law. Moreover, even if employees are generally considered as acting on behalf of the entity that employs them as a result of which they can not constitute autonomous undertakings, ${ }^{101}$ the status of employee does not exclude that a person can be considered as an undertaking. Insofar as the employee pursues his own economic interests, independent of the employer, he may be considered an undertaking in the sense of Article $81 \mathrm{EC} .^{102}$ In the case of sportsmen, one may think of a professional football player as one who enters into a sponsoring agreement with a major sponsor.

\section{Restriction of competition or abuse of a dominant position}

A second key question to address when analysing the applicability of EC competition law, is whether the sporting rule at stake restricts competition within the meaning of Article 81(1) EC or constitutes an abuse of a dominant position under Article $82 \mathrm{EC}$. Therefore, it must first be analysed whether the rule in question, which normally arises from the statutes of a sporting federation, can be considered as an 'agreement', 'decision', or 'concerted practice'. Although FIFA claimed in the Balog case that its regulations could not be considered as an agreement between undertakings or a decision of an association of undertakings, ${ }^{103}$ rules set

\footnotetext{
${ }^{92}$ Case COMP/37.806, para 25.

${ }^{93}$ Case T-193/02 Laurent Piau v Commission [2005] ECR II-209, para 69.

${ }^{94}$ Case COMP/C.2-37.398 [2003] OJ L 291/25, para 106; Case IV/33.384 and IV/33.378, paras 52 and 53; Case T193/02 Laurent Piau v Commission [2005] ECR II-209, para 71.

${ }_{95}$ Case T-193/02 Laurent Piau v Commission [2005] ECR II-209, para 69.

96 ibid., para 69.

${ }_{97}$ IV/33.384 and IV/33.378, para 47; Case T-193/02 Laurent Piau v Commission [2005] ECR II-209, para 72.

${ }^{98}$ Case COMP/C.2-37.398, para 106.

99 V. Louri, "Undertaking' as a Jurisdictional Element for the Application of EC Competition Rules', (2002) Legal Issues of Economic Integration 143, 151.

100 Joined case C-51/96 and C-191/97 Deliège v Ligue francophone de judo et disciplines associées e.o. [2000] ECR I-2549, paras 56-57.

101 Joined case 40-48, 50, 54-56, 111, 113 and 114/73 Suiker Unie e.o. v Commission [1975] ECR 1663; V. Louri, "Undertaking' as a Jurisdictional Element', n 99 above, 149.

${ }_{102}$ Case IV/28.996 [1976] OJ L 254/40.

${ }^{103}$ Case C-264/98 Balog v Royal Charleroi Sporting Club ASBL (removed from the register on 2/4/01), Rapport d'audience, para 34 .
} 
down by sporting federations are usually considered to be decisions by an association of undertakings. In Bosman, Advocate General Lenz held that the nationality clauses and the transfer rules concerned decisions of associations of undertakings, ${ }^{104}$ whereas the Court of First Instance came to the same conclusion with regard to the players' agents' regulations. ${ }^{105}$ In Meca Medina, the Court of Justice held - admittedly only implicitly - that the IOC antidoping regulations as implemented by the international swimming federation, could be considered a decision of an association of undertakings. ${ }^{106}$

Thereafter, it must be analysed as to whether the rule at stake has an objective to restrict or distort, or an effect upon the restriction or distortion of, competition within the common market. In his opinion in Bosman, Advocate General Lenz confirmed the Commission's point of view. ${ }^{107}$ According to the Commission and Lenz, the nationality clauses restricted the possibilities for clubs to compete with each other by engaging players. That is a restriction of competition between those clubs. In fact, this can be seen as a way of sharing 'sources of supply' within the meaning of Article 81(1)(c) EC. The transfer rules and the payment of a transfer sum were considered as rules replacing 'the normal system of supply and demand by a uniform machinery which leads to the existing competition situation being preserved and the clubs being deprived of the possibility of making use of the chances, with respect to the engagement of players, which would be available to them under normal competitive conditions'. Lenz came to the conclusion that the restriction of competition was not only the effect of the rules in question, but was also intended by the clubs and associations. ${ }^{108}$ However, this concept remains rather scantily elaborated in the case-law. In Meca-Medina+, the ECJ only briefly touched upon this aspect by stating that the anti-doping rules were capable of producing adverse effects on competition because an athlete's unwarranted exclusion from sporting events would lead to 'impairment of the conditions under which the activity at issue is engaged in'. ${ }^{109}$ The analysis of this aspect by the CFI in Piau can be criticised because it did not clearly indicate an anticompetitive object or effect to justify the application of Article 81(1) EC. ${ }^{110}$ Instead, the Court of First Instance only held that the compulsory licence constitutes a barrier to the access to the economic activity of players' agents, and therefore 'necessarily affects competition'.111 The test carried out by the CFI closely relates to the concept of 'market access' which is normally used in a free movement context. ${ }^{12}$

An aspect barely taken into account in sport related competition cases is the fact that the prohibition of Article 81(1) EC covers only appreciable interferences with competition. ${ }^{113} \mathrm{~A}$ possible explanation might be that sporting associations often hold a (quasi) monopoly position in their sport. Closely related to this is the concept 'relevant market'. Especially in the context of Article $82 \mathrm{EC}$, but also within the context of Article 81(1) EC, it is important to determine the relevant market, which entails a geographical and a product market. ${ }^{114}$ The geographical market covers the territory of the associations/clubs where a given sporting rule applies. In her de facto opinion in Balog, Advocate General Stix-Hackl emphasised that the fact that sport has certain particular features which distinguish it from other economic

\footnotetext{
104 Conclusion Advocate General Lenz in Case C-415/93 Union Royale Belge des Sociétés de Football Association v Bosman [1995] ECR I-4921, para 258.

105 Case T-193/02 Laurent Piau v Commission [2005] ECR II-209, para 75.

${ }^{106}$ Case C-519/04 P Meca-Medina \& Majcen v Commission [2006] ECR I-6991, para 45.

107 Conclusion Advocate General Lenz in Case C-415/93 Union Royale Belge des Sociétés de Football Association v Bosman [1995] ECR I-4921, para 262.

108 idem.

${ }^{109}$ Case C-519/04 P Meca-Medina \& Majcen v Commission [2006] ECR I-6991, para 47.

110 D. Waelbroeck and P. Ibáñez Colomo, 'Case C-171/05 P, Laurent Piau, Order of the Court of Justice (Third Chamber) of 23 February 2006, [2006] ECR I-37', (2006) CML Rev. 1743, 1749.

${ }^{111}$ Case T-193/02 Laurent Piau v Commission [2005] ECR II-209, para 101.

112 Case C-384/93 Alpine Investments BV v Minister van Financiën [1995] ECR I-1141, para 38; Case C-415/93 Union Royale Belge des Sociétés de Football Association v Bosman [1995] ECR I-4921, para 103; J.W. Van de Gronden, 'annotation Piau, T-193/02', (2006) SEW 31, 34.

113 Case 5/69 Völk v Vervaecke [1969] ECR 295.

${ }^{114}$ Case C-234/89 Delimitis v Henninger Braeu [1991] ECR I-935, para 16.
} 
sectors does not mean that there cannot be a market, or even several markets. ${ }^{115}$ Subsequently, when scrutinising the transfer rules, she indicated that there were three interconnected - markets. ${ }^{116}$ The first is the exploitation market where both clubs and associations act as undertakings and exploit their performances, e.g. by selling broadcasting rights. The second market is the contest market, 'in which the typical product of professional sport is produced: the sporting contest'. ${ }^{117}$ The third market is the supply market where the clubs 'sell' and 'buy' players. ${ }^{118}$ Although this analysis focused on the transfer rules in football, it seems that it can for the most part be transposed to other major (team) sports. Both in Meca Medina and in Piau, the concept of relevant market received little attention. In Meca Medina, one could suggest that the contest market was at stake, although this was not explicitly stated by the Community judges. In Piau, the CFI mentioned that the rules in question affected the 'market for the provision of services where the buyers are players and clubs and the sellers are agents'. ${ }^{119}$

Concerning the analysis of whether a sporting organisation holds a dominant position within the meaning of Article $82 \mathrm{EC}$, it has already been stated that sporting associations often have a monopoly in their sport and can be considered dominant in the market of the organisation of sporting activities for their particular sport. In its judgment on the applicability of Article 82 EC in Piau, the CFI found, contrary to the Commission which had held that Article 82 EC was not applicable as FIFA was not active on the market for the provision of advise of players, that FIFA - although not itself an economic operator that buys the services of players' agents - held a collective dominant position on the market at issue as the emanation of the national associations and the clubs. ${ }^{120}$ According to the Court of First Instance, FIFA's agents regulations result in the clubs 'being so linked as to their conduct on a particular market that they present themselves on that market as a collective entity vis-à-vis their competitors, their trading partners and consumers'.121 This decision correlates with the finding of Advocate General Lenz in Bosman that the clubs in a professional league are 'united by such economic links' that together they are to be regarded as having a dominant position', although he did not consider UEFA's or FIFA's position. ${ }^{122}$

\section{Effect on trade between Member States}

A last element that needs to be considered when analysing the applicability of Articles 81 (1) and $82 \mathrm{EC}$ concerns the effect of the rule in question on trade between Member States. Again, this aspect received little attention in sport related cases. However, the broad definition of this concept - a direct or indirect, actual or potential, influence on the pattern of trade between Member States suffices $-{ }^{123}$ seems to pose little problems in the case of sport. Rules originating from European or international sporting federations are applicable in several countries and are likely to affect trade between Member States; besides, given the international context of professional sport, rules originating from national sporting federations might also affect trade between Member States. Moreover, the reasoning that a sporting rule, e.g. on the transfer of players, would have nothing to do with trade, ${ }^{124}$ can be overruled by the fact that also the concept of trade has been interpreted broadly. ${ }^{125}$

\footnotetext{
${ }^{115}$ A. Egger and C. Stix-Hackl, 'Sports and Competition Law', n 14 above, 86.

116 ibid., 86-87.

117 ibid., 86.

118 ibid., 87.

119 Case T-193/02 Laurent Piau v Commission [2005] ECR II-209, para 112.

120 ibid., paras 107-116.

121 Joined case C-395/96 P and C-396/96 P Compagnie maritime belge transports SA eo. v Commission [2000] ECR I-1365, para 44.

122 Conclusion Advocate General Lenz in Case C-415/93 Union Royale Belge des Sociétés de Football Association v Bosman [1995] ECR I-4921, para 285.

${ }^{123}$ Case 5/69 Völk v Vervaecke [1969] ECR, para 5.

${ }^{124}$ Argument put forward by UEFA in Bosman.

${ }^{125}$ Case 172/80 Züchner v. Bayerische Vereinsbank [1981] ECR 2021, para 18.
} 


\section{Wouters approach or Article 81(3) EC?}

After Meca-Medina, it seems clear that when a given sporting rule meets the conditions of Article 81(1) EC the Wouters test should be applied. Therefore, one has to analyse whether the rule at stake pursues a legitimate objective and whether its anti-competitive effects are inherent in the pursuit of this objective and are proportionate. Because several 'sporting' objectives - like maintaining certain equality between participants and the uncertainty of the results or the protection of athletes' health - ${ }^{126}$ have been accepted as legitimate, the main assessment will relate to the proportionality principle. This is a factual analysis which has to be carried out by the European Commission and the Community judges.

Once established that a certain sporting rule does not meet the criteria set out in Wouters, one might look for justification under Article 81(3) EC. ${ }^{127}$ When the four cumulative conditions of this provision - improvement in the production or distribution of goods or the promotion of technical or economic progress; allowing consumers a fair share of the resulting benefits; without imposing restrictions which are not indispensable to the attainment of these objectives; and without affording the parties the possibility of substantially eliminating competition - are met, the prohibition under Article 81(1) may be declared inapplicable. A question arising in the sporting context is whether socio-political motives can play a role in the analysis under Article 81(3). On the basis of the Commission Guidelines on the application of Article 81(3), it seems that the answer should be negative. ${ }^{128}$ Following these guidelines, goals pursued by other Treaty provisions can only be taken into account to the extent that they can be subsumed under the four conditions of Article 81(3). ${ }^{129}$ In reality, these guidelines are to a large extent based on valid economic considerations, what might, as stated by Bourgeois and Bocken, 'result in a too limited and reduced scope of the exception rule of Article 81(3) EC'.130

Apparently, the CFI disregarded these guidelines when assessing the FIFA players agents' regulations in Piau. Admittedly, the CFI came to the conclusion that the conditions of Article 81(1) were fulfilled without making a detailed analysis. The Court did not apply the Wouters test, but directly continued by considering whether the conditions of Article 81(3) EC were met. Again, its analysis was rather vague. Referring to the fact that apart from France, there would be no national regulation governing the occupation of sports agents as well as to the fact that the players' agents would not have a collective organisation, the Court of First Instance came to the conclusion that the mandatory licence system results in a qualitative selection, appropriate for the attainment of the double objective of raising professional and ethical standards for the occupation of players' agents in order to protect players. ${ }^{131}$ It should be noted that the analysis of facts of the CFI lacks some nuance. In particular, the Court's finding that there is barely any national regulation on players' agents and that there is no collective organisation of players' agents seems to be inaccurate. ${ }^{132}$ On appeal, the ECJ rejected Piau's pleas, without giving much guidance. ${ }^{133}$

Both the case of Meca-Medina and the case of Piau illustrate that sport does not a priori escape EC competition law and that the existing EC legal framework is sufficiently flexible to

\footnotetext{
${ }^{126}$ Case C-415/93 Union Royale Belge des Sociétés de Football Association v Bosman [1995] ECR I-4921, para 106; Case C-519/04 P Meca-Medina \& Majcen v Commission [2006] ECR I-6991, paras 43-45.

${ }^{127}$ Article 82 EC does not contain a similar paragraph 3, but as Jones and Sufrin highlight, the Commission and the Court of Justice developed the concept of 'objective justification' to distinguish between abusive conduct contrary to Article $82 \mathrm{EC}$ and conduct which is pursued for legitimate commercial reasons. 'If the conduct is objectively justified or 'necessary' it is outside Article 82 '. A. Jones and B. Sufrin, EC Competition Law , n 66 above, p 282-287.

128 Guidelines on the application of Article (81)3 of the Treaty [2004] OJ C 101/97.

129 ibid., para 42.

$130 \mathrm{~J}$. Bourgeois and J. Bocken (2005), 'Guidelines on the Application of Article 81(3) of the EC Treaty or How to Restrict a Restriction', Legal Issues of Economic Integration 111, 119.

${ }^{131}$ Case T-193/02 Laurent Piau v Commission [2005] ECR II-209, paras 102-103.

132 R. Branco Martins, 'The Laurent Piau Case of the ECJ on the Status of Players' Agents', (2005) 3-4 ISLJ 8; A. Vermeersch, 'PIAU t. Commissie: Sportieve competitie eindigt op 0-1, (2005) NTER 101.

${ }^{133}$ Case C-171/05 P Laurent Piau v Commission [2006] I-37.
} 
take into account the specific characteristics of sport. However, the approach in both cases differs. One might wonder whether this difference is relevant for the sporting world. From the viewpoint of the sporting federations, the key issue is to avoid getting a 'European red card'. The underlying rationale seems of little importance. However, from a legal point of view, the choice between the Wouters approach and the application of Article 81(3) EC has some bearing on the burden of proof. Under Article 2 of Regulation 1/2003 the burden of proving an infringement of Article $81(1)$ EC rests on the authority or party alleging the infringement. ${ }^{134}$ The burden of proving that the conditions of Article 81(3) EC are met rests on the defender.

\section{Conclusion: Legal certainty and the future of sports governance in Europe}

The application of EC law to sport provokes repeatedly, most recently in the Parliaments' report on professional football, calls for more legal certainty. The Meca-Medina ruling from the ECJ might have a double impact on the relationship between EC law and sport. On the one hand, by clarifying that sporting rules do not automatically fall outside the scope of EC law, the Meca-Medina ruling might form an incentive for sportsmen and other parties to challenge the role and the action of sporting associations under EC law. A similar development should not be supported as such. In the concrete case of doping offences, for example, the Community Courts seem not to be the most appropriate instances in which to settle these cases. This is not to say that the sporting community should not organise itself without taking into account the requisites of EC law. On the other hand, the application of the Wouters test in Meca-Medina provides useful guidance for the future application of EC law to sport.

Against the background of the quest for greater legal certainty, several options occur with regard to the future application of EC competition rules to sport. ${ }^{135}$ So far, the relationship between sport and EC law has been based on a case-by-case analysis and a soft law approach, with the Helsinki report and the Nice Declaration as the most prominent examples. Other possibilities relate to a Social Dialogue, ${ }^{136}$ a Treaty revision or a block exemption. The option of a Treaty revision could take several forms. Theoretically, one could provide sport with exemptions from competition (and free movement) law provisions by amending Articles 81 and 82 (and 39) EC. Arguably, this seems excessive and the Constitutional Treaty did not follow this line. ${ }^{137}$ A block exemption seems also unlikely. This technique is used by the Commission (in the form of a Regulation) in order to exempt particular practices or branches from the application of Article $81 \mathrm{EC}$. The question remains as to what particular sporting practices should be exempted. As a block exemption only relates to competition law, a very generous block exemption for sport might undermine the Court's case law on free movement. ${ }^{138}$ In addition, it seems that no consensus exists within the Commission on granting sport such an exemption status. ${ }^{139}$

On the basis of the forgoing, it seems appropriate to maintain the current combination of a case-by-case analysis and a soft law approach. As has already been stated, the existing EC legal framework is sufficiently flexible to take account of the specific characteristics of sport. Both for the Community judges and for the Commission this seems to be a workable tool in order to maintain a balance between the EC 'rules of the game' and the specific nature of sport. Although not all details have been worked out yet, the outcome of future litigation seems fairly 'predictable'. On the basis of the existing case-law, it should be feasible to

\footnotetext{
134 [2003] OJ L 1.

135 See also Project commissioned by the Committee on the Internal Market and Consumer Protection of the European Parliament, 'Professional Sport in the Internal Market', Project No IP/A/IMCO/ST/2005-004, September 2005, $92 \mathrm{p}$.

136 ibid., p 65-73.

137 [2004] OJ 2004 C 310.

$138 \mathrm{~S}$. Weatherill, 'Limits to the autonomy of sports governing bodies under EC law: legal perspectives on the 'Arnaut Report", Concluding Conference Social Dialogue, Brussels, 27 November 2006.

139 'Professional Sport in the Internal Market', n 135 above, p 83.
} 
predict whether or not a sport related rule is likely to be prohibited under EC (competition) law. The concrete legal reasoning behind such judgments might need further elaboration. The Oulmers case, where the Belgian Charleroi football team - supported by the G-14 challenges the players release system of FIFA, ${ }^{140}$ will provide the Court of Justice with the first possibility to do so. More concretely, the Belgian judge referred the following preliminary question to the Court of Justice: 'Do the obligations on clubs and football players having employment contracts with those clubs imposed by the provisions of FIFA's statutes and regulations providing for the obligatory release of players to national federations without compensation and the unilateral and binding determination of the co-ordinated international match calendar constitute unlawful restrictions of competition or abuses of a dominant position or obstacles to the exercise of the fundamental freedoms conferred by the EC Treaty and are they therefore contrary to Articles 81 and 82 of the Treaty or to any other provision of Community law, particularly Articles 39 and 49 of the Treaty?'. ${ }^{141}$ Without entering into detail, one might argue that this rule seems to be contrary to EC law, not so much because there cannot be a system of (mandatory) players release as such, but rather because the current system is not proportionate. It seems totally acceptable that clubs can be obliged to release players to participate in international competitions. It seems to be unacceptable that they have to do so without any compensation and bear the risk of potential injuries. ${ }^{142}$

By way of conclusion, one might say that all's fair in sport and competition, provided it is proportionate, or, as Weatherill states forcefully, sporting bodies enjoy a 'conditional autonomy' when setting the rules of the game. ${ }^{143}$ In order to maintain the current balance, the dialogue between the sporting world and the Community institutions must be preserved and enhanced. Only on the basis of mutual understanding and respect may the sporting associations keep their leading role.

\footnotetext{
140 Pending case C-243/06 SA Sporting du Pays de Charleroi and Groupement des clubs de football européens. 